\title{
GPER1 Gene
}

National Cancer Institute

\section{Source}

National Cancer Institute. GPER1 Gene. NCI Thesaurus. Code C106198.

This gene plays a role in both estrogen binding and G protein-coupled receptor signaling. 